\title{
EXPERIMENTAL STUDIES ON BEHAVIOUR OF FERROCONCRETE
}

\section{BEAMS}

\author{
Manasa $\mathbf{B}^{1}$, Sowmyashree $\mathrm{T}^{2}$, Sharath Babu Khedagi ${ }^{3}$ \\ ${ }^{I} P G$ Student, Department of Civil Engineering, Vijaya Vittala Institute of Technology, Karnataka, India \\ ${ }^{2}$ Assistant Professor, Civil Engineering Department, Vijaya Vittala Institute of Technology, Karnataka \\ ${ }^{3}$ Assistant Professor, Civil Engineering Department, Vijaya Vittala Institute of Technology, Karnataka
}

\begin{abstract}
Ferroconcrete is a new generation type of concrete and it is an alternative material for a light weight structural elements. Ferroconcrete consists of cement, jelly chips, mesh and water. This work deals with an experimental study on behavior of ferroconcrete beams. Mix proportions 1:3 i.e. cement: jelly chips with water-cement ratio 0.45 were selected. The overall dimensions of beam are 150X150X2000mm and it is reinforced with compressive strength of about 16.32MPa was obtained at 28 days for mix proportion of 1:3 and water-cement ratio of 0.45. Flexural and Impact strength test was conducted. The cracks are due to loading and failure cracks developed due to ultimate load. Flexure strength of produced specimens was $13.6 \mathrm{~N} / \mathrm{mm} \mathrm{m}^{2}$ and it has good enough to take impact energy of 6415Joules.
\end{abstract}

Keywords: Ferroconcrete, Jelly chips, GI Mesh, Skeleton Steel, Water-cement ratio, Compressive strength, Flexural Strength, Impact Energy.

\section{INTRODUCTION}

Concrete is a primary material used in construction around the world and most useful in civil engineering works. It extensively used in light of fact that it offers strength and durability at a reasonable cost. It is a man made product which made up of cement, aggregates, water and admixtures. Now a day's ferrocement is most significantly used in a construction of light weight elements. In ferroconcrete constituent material sand is replaced by jelly chips. Ferroconcrete is generally misunderstood to be a new type of cement. The definition of ferroconcrete is "A highly versatile form of reinforced concrete made up of galvanized iron mesh, cement, jelly and water in which closely spaced mesh are layers by layer impregnated with high strength cement and jelly mix". In this investigation sand is replaced by jelly chips and attempt is made to design the ferroconcrete beams and cast them to carry out Flexural and Impact test to study behavior of bending and stresses developed in the beams. The ingredients required for ferroconcrete are easily available in every part of our country, and as such it can be very easily moulded or cast in any shape or form and has been used as construction material by architects and engineers for seeking their dreams coming true whenever the other materials deceived.

\subsection{Review of Literature}

As per Shang Shouping, Zeng Linghong, Peng Hui and Fang Ping [1] study, that ferrocement technology is an efficient method of beam strengthening. The bending behavior of beams strengthened by ferrocement thin plates reinforced with steel wire mesh was experimentally investigated. The results show that ferrocement can obviously increase the load bearing capacity and resisting capacity and improve the bending stiffness of beam. As per Antonine E. Naaman and Surendra P. Shah [2] study, it is to better understand ferroconcrete as an engineering material and predict its design properties. In this they have studied effects of types, sizes, volume of wire mesh on ferroconcrete in uni-axial tension, they observed that ultimate strength of ferroconcrete is that of mesh, and found that modulus of elasticity can be predict from those mortar mesh. Despite the fact that many researchers have been done on ferrocement beams. There is no research work done on ferroconcrete beam. Based on experimental work, it can be presume that jelly chips can be used in place of sand, so compressive strength and impact energy have been improved. In these reviews they discussed that by increasing the number of mesh layers, increases ductility of the ferroconcrete elements also ferroconcrete are good seismic and more economy as compared to conventional concrete. The researches on ferroconcrete beams are still under investigation.

\subsection{Objectives of Study}

The goal of this study is to access to solve the problems due to huge requirement of raw material in nature for the manufacturing of conventional building material and also reduces hazards caused by wastes of industries on the environment. The finding of alternatives low cost and environmental sustainable building materials from industrial residue is a best economic way to overcome from problems and hazards. Importance must be given to cheap, locally available and environmental friendly building materials and 
hence it is very necessary to utilize and check out the suitable waste products during the construction process. The major objectives of this study are as follows.

1. To carry out the preliminary test on the materials used in study i.e. specific gravity, water absorption, impact, crushing test etc.

2. The mix proportions of cement, jelly chips are fixed based on trial and error method depending upon strength and workability.

3. To find out optimum water-cement ratio to produce ferroconcrete element.

4. To use jelly chips (passing from $4.75 \mathrm{~mm}$ and retained in $2.36 \mathrm{~mm}$ IS Sieves) in place of sand and to replace reinforcement bars by GI mesh which is more durable than wood and much cheaper than steel, in the production of ferroconcrete beams.

5. To produce light weight ferroconcrete beam of size 150X150X2000mm.

6. To determine the strength properties of produced ferroconcrete beams for Flexural and Impact strength.

\subsection{Methodology}

The following are the methods that followed in the production of ferroconcrete beams.

1. The material has been procured and a property of materials has been characterized.

2. Preparation of ferroconcrete cubes with different proportion of cement and jelly i.e. 1:3, 1:4 and 1:5 with suitable water quantity.

3. The compressive strength has been determined at 7days and 28days for selection of water-cement ratio.

4. Flow table test was carried out for fresh concrete to check the flow ability of the mix.

5. For selected mix proportion and water-cement ratio, beam specimen of size $150 \mathrm{X} 150 \mathrm{X} 2000 \mathrm{~mm}$ were casted with two layers of Galvanized Iron mesh to obtain 28days strength.

6. For produced specimens flexural and impact strength test has been conducted and also crack width and its pattern has been analyzed.

\subsection{Casting Process}

The following are the steps which are involved in the Casting and curing process at job site.
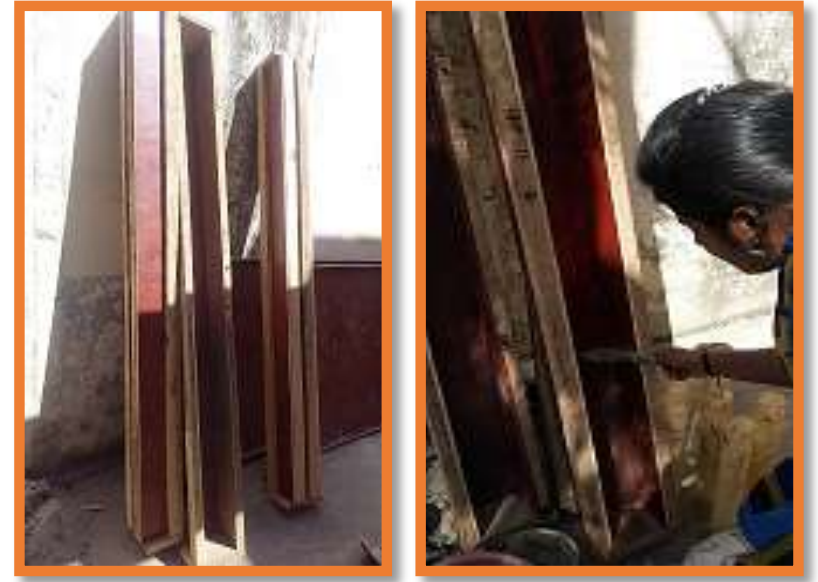

Fig 1: Preparation of Mould and Lubricating Process
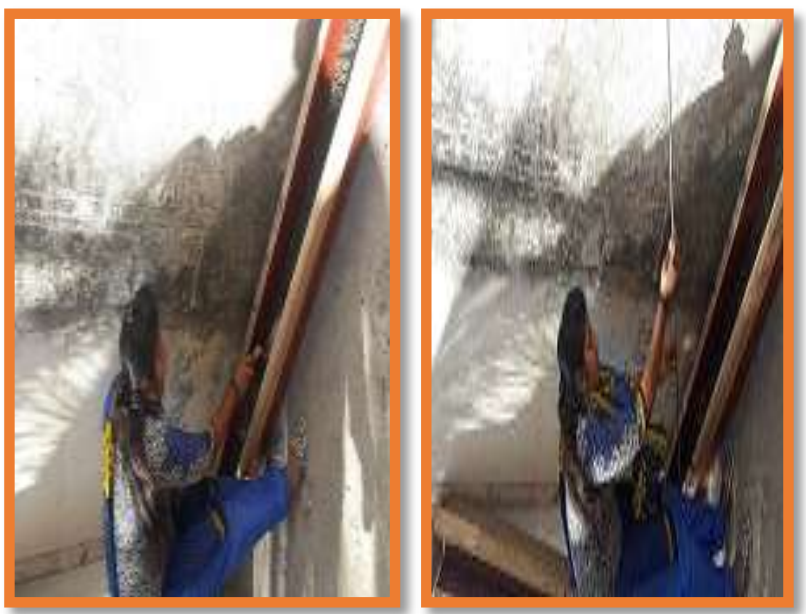

Fig 2: Pouring of Concrete $1^{\text {st }}$ Layer and Lying of Skeleton Steel
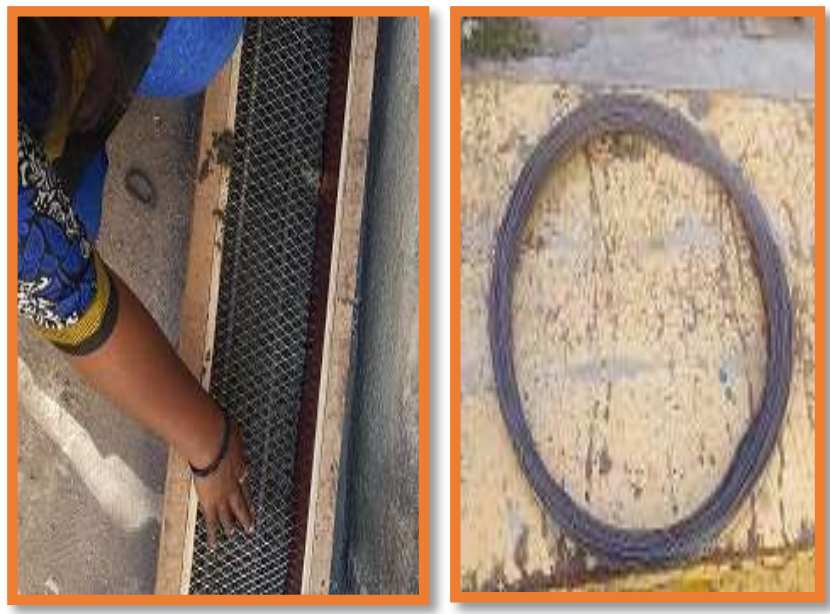

Fig 3: Pouring of Mesh $1^{\text {st }}$ Layer with Binding Wire 

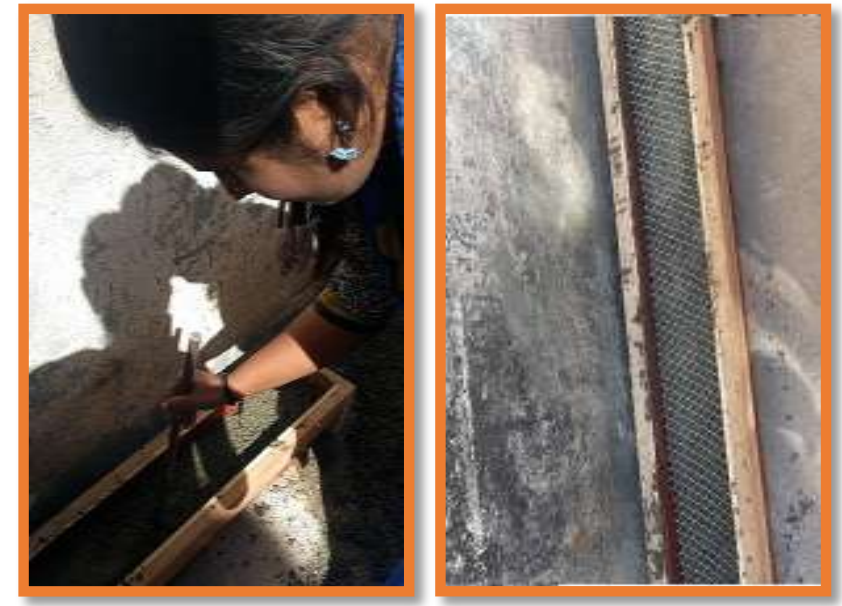

Fig 4: Pouring of Concrete and Mesh $2^{\text {nd }}$ Layer
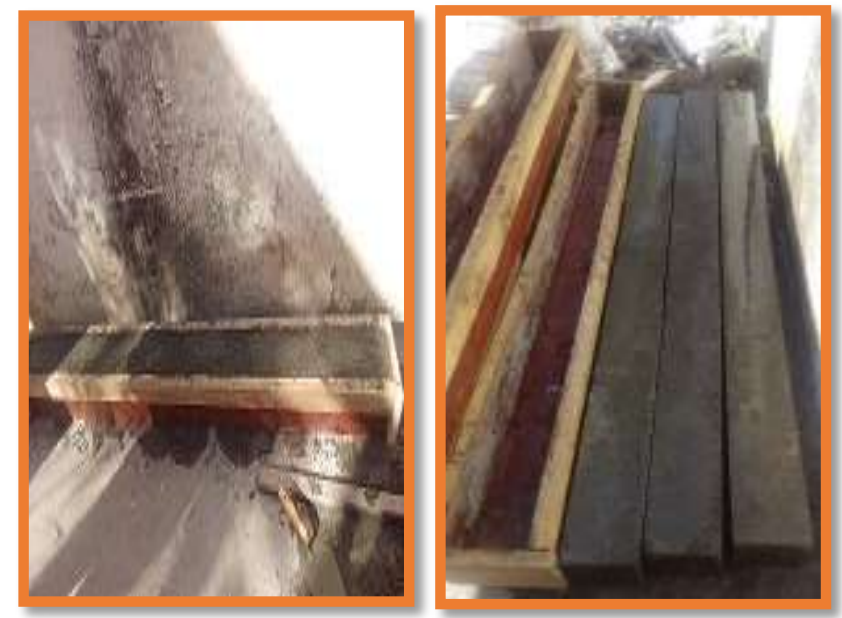

Fig 5: Pouring of Concrete final layer and De-molding Process

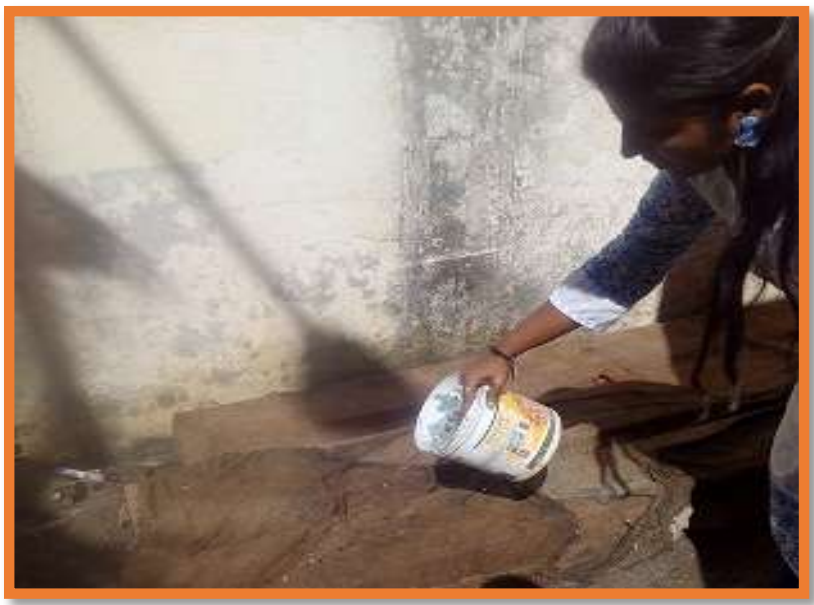

Fig 6: Curing Process for 28days

\section{LABORATORY INVESTIGATION}

The materials utilized for the manufacture of ferroconcrete in this study are cement, jelly chips, GI mesh, skeleton steel and water. The following are the test results obtained in a laboratory. In this study Birla super 53grade OPC complying to IS: 12269-1987 has been used. Skeleton steel of $8 \mathrm{~mm}$ were used as a supporting purpose. Jelly chips were used as a replacement of sand hence its properties has been studied thoroughly and results are tabulated as follows.

Table - 1: Properties of Jelly Chips

\begin{tabular}{|l|l|}
\hline Physical Properties & Test Results \\
\hline Specific Gravity & 1.92 \\
\hline Water Absorption (\%) & 40.1 \\
\hline Crushing Strength (\%) & 45 \\
\hline Impact Strength (\%) & 47 \\
\hline Bulking of aggregates (\%) & 12.8 \\
\hline Size & $\begin{array}{l}\text { Passing from } \\
4.75 \mathrm{~mm} \text { retained on } \\
\end{array}$ \\
\hline
\end{tabular}

Table - 2: Properties of GI Mesh

\begin{tabular}{|l|l|l|}
\hline Type of Mesh & $\begin{array}{l}\text { Yield Strength } \\
\text { (MPa) }\end{array}$ & $\begin{array}{l}\text { Modulus of } \\
\text { Elasticity (Gpa) }\end{array}$ \\
\hline $\begin{array}{l}\text { Expanded GI } \\
\text { Mesh }\end{array}$ & $360-390$ & $75-135$ \\
\hline
\end{tabular}

The tests are conducted to know the basic characteristic of each material. After this water-cement ratio found out for different proportion i.e. 1:3, 1:4, and 1:5 with the suitable water content.

Table -3 : w/c ratio for mixed proportions

\begin{tabular}{|l|l|l|l|l|l|l|}
\hline $\begin{array}{l}\text { Mi } \\
\mathbf{X} \\
\text { Pro } \\
\text { por } \\
\text { tio } \\
\text { ns }\end{array}$ & $\begin{array}{l}\text { Ceme } \\
\text { nt }\end{array}$ & Jelly & $\begin{array}{l}\text { Wate } \\
\mathbf{r}\end{array}$ & $\begin{array}{l}\text { w/c } \\
\text { rati } \\
\mathbf{o}\end{array}$ & $\begin{array}{l}\mathbf{7 d a y s} \\
\text { streng } \\
\text { th } \\
\mathbf{( N / m} \\
\left.\mathbf{m}^{2}\right)\end{array}$ & $\begin{array}{l}\mathbf{2 8 d a y} \\
\mathbf{s} \\
\text { streng } \\
\text { th } \\
\mathbf{( N / m} \\
\left.\mathbf{m}^{2}\right)\end{array}$ \\
\hline $1: 3$ & 1200 & 3600 & 600 & 0.5 & 6.48 & 11.79 \\
\hline $\mathbf{1 : 3}$ & $\mathbf{1 2 0 0}$ & $\mathbf{3 6 0 0}$ & $\mathbf{5 4 0}$ & $\mathbf{0 . 4 5}$ & $\mathbf{9 . 5 6}$ & $\mathbf{1 6 . 3 2}$ \\
\hline $1: 4$ & 1200 & 4800 & 650 & 0.54 & 4.41 & 05.27 \\
\hline $1: 5$ & 1200 & 6000 & 1000 & 0.83 & 0.62 & 06.12 \\
\hline
\end{tabular}




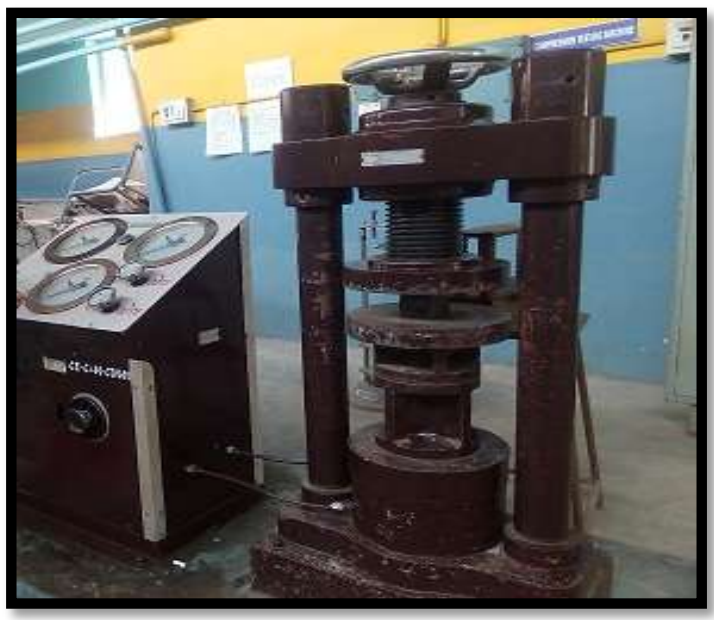

Fig -7: Compression Testing Machine

After finding compression strength of different mix for 7 days and 28days, a mix of 1:3 with w/c ratio 0.45 is chosen as its compressive strength is $16.32 \mathrm{~N} / \mathrm{mm}^{2}$ after 28 days curing.

\subsection{Flow Table Test}

This test was done for deciding the workability of mix. The workability is done by means of flow table test. Flow is defined as the increase in the diameter of a base of a mortar mass. The apparatus used for flow table test consisting of cast iron frame, brass table of circular in shape and conical mould of size $12.5 \mathrm{~mm}$ diameter. The arrangement has been carried out in such a way that rotation is given through a cam and shaft arrangement the table was dropped at a height of $12.7 \mathrm{~mm}$
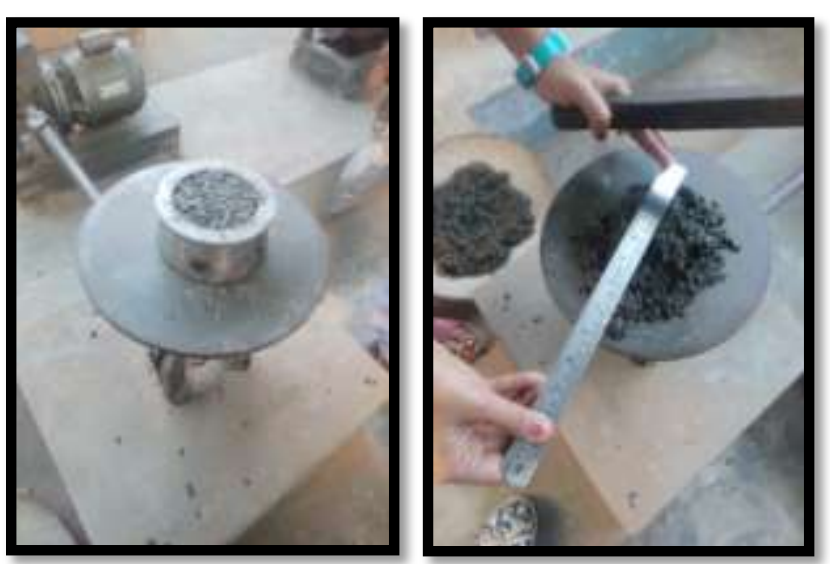

Fig -8: Flow Table Test

\subsection{Flexural Strength Test}

Flexural strength is an indirect measure of tensile strength of mix. It measure of the maximum stress on the tension face of an unreinforced concrete beam at the point of failure in bending.

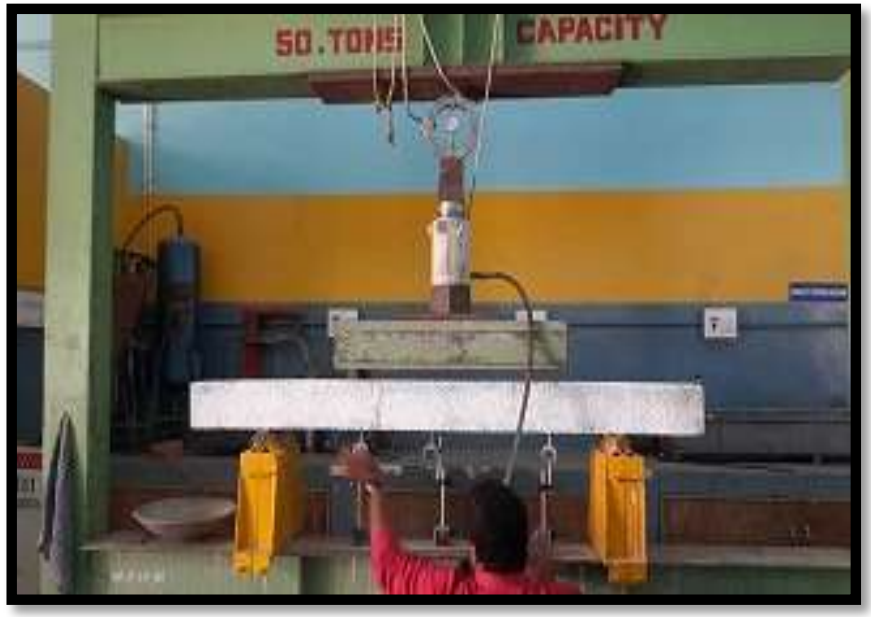

Fig -9: Flexural Strength Test

\subsection{Impact Strength Test}

To determine the energy absorbed by the ferroconcrete element impact test is conducted. From this test it is easy to find the toughness of the beam element.

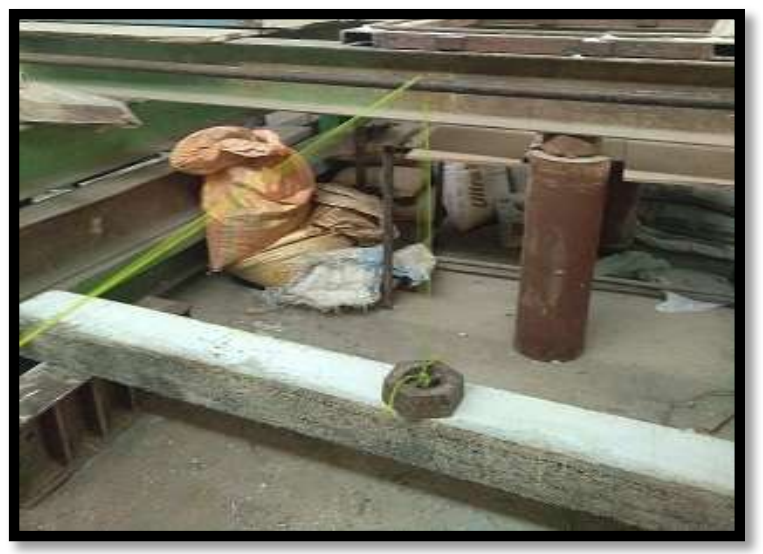

Fig - 10: Impact Strength Test

\section{RESULTS AND DISCUSSIONS}

In the experimental study the tests are conducted and results are tabulated and graphs are plotted for respective values.

\subsection{Flow Table Test}

Table - 4: Flow Table Test Results

\begin{tabular}{|l|l|}
\hline $\begin{array}{l}\text { Water-cement } \\
\text { Ratio }\end{array}$ & $\begin{array}{l}\text { Measurement of Flow in } \\
\text { mm }\end{array}$ \\
\hline 0.45 & 133 \\
\hline 0.5 & 135 \\
\hline 0.54 & 139 \\
\hline
\end{tabular}




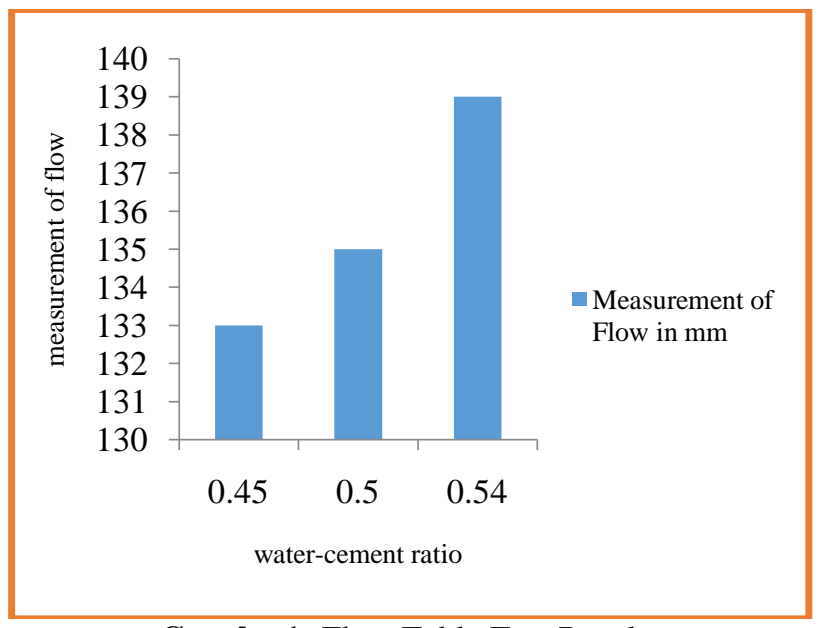

Graph -1: Flow Table Test Results

From this graph water cement ratio increases the measurement of flow also increases. The obtained value is suitable for casting mix proportion 1:3 and water-cement ratio 0.45 is chosen.

\subsection{Compressive Strength Test}

Table - 5: Compressive Strength Test Results

\begin{tabular}{|l|l|l|l|}
\hline Proportions & W/C Ratio & $\begin{array}{l}\text { 7days } \\
\text { Strength }\end{array}$ & $\begin{array}{l}\text { 28days } \\
\text { Strength }\end{array}$ \\
\hline $1: 3$ & 0.45 & 09.56 & 16.32 \\
\hline $1: 4$ & 0.50 & 06.48 & 11.79 \\
\hline $1: 5$ & 0.54 & 04.41 & 05.37 \\
\hline
\end{tabular}

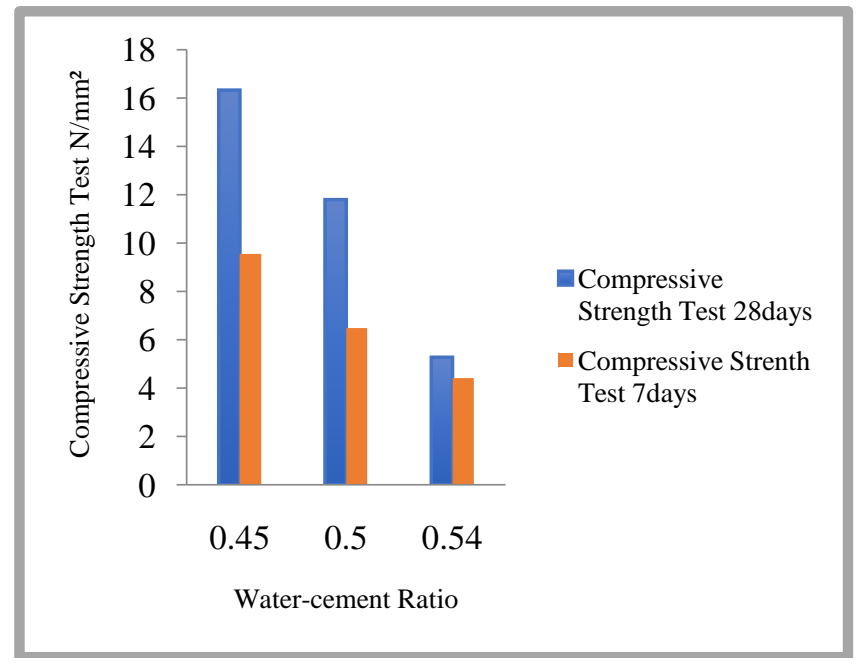

Graph -2: Compression Strength Test Results

From this graph the achieved strength is sufficient for construction of structural elements.

\subsection{Flexural Strength Test}

The flexural strength of the beam is carried out and test results obtained are as follows. The test values are compared with analytical using PL / $\left(\mathrm{bd}^{2}\right)$ formula as well as practical values.
Table - 6: Flexural Strength Test Results

\begin{tabular}{|l|l|}
\hline Average Ultimate Load $(\mathrm{kN})$ & 19.5 \\
\hline Flexural Strength $\left(\mathrm{N} / \mathrm{mm}^{2}\right)$ & 13.16 \\
\hline \multicolumn{2}{|l|}{ Reference Ferro cement Beam } \\
\hline Ultimate Load $(\mathrm{kN})$ & 18.6 \\
\hline Flexural Strength $\left(\mathrm{N} / \mathrm{mm}^{2}\right)$ & 11.9 \\
\hline
\end{tabular}

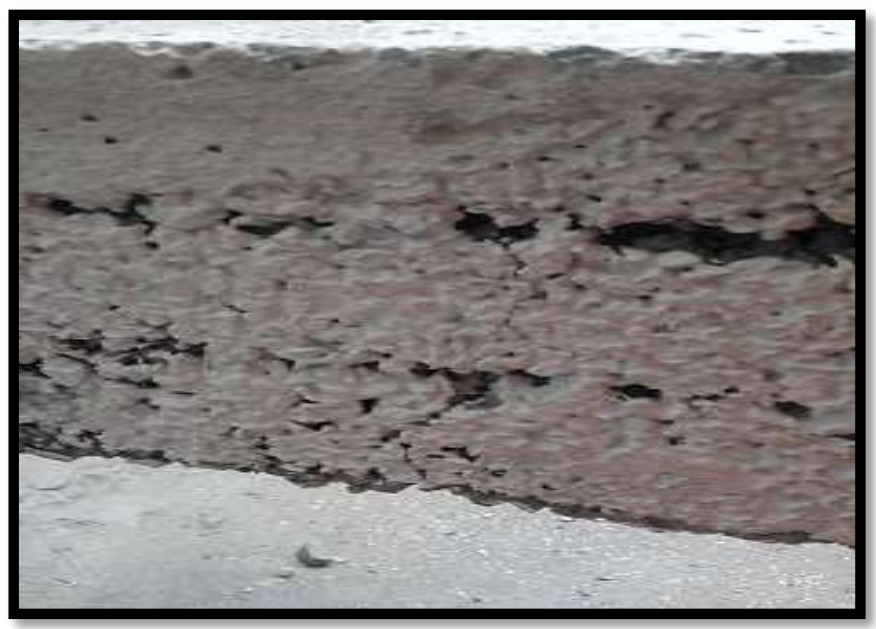

Fig -11: Flexural Test Crack

When load increases the deflection also increases. It means that indicates it is an elastic material. When compared with ferro cement beam the load carrying is same as that of ferroconcrete beams.

\subsection{Impact Strength Test}

The following table shows the energy observed by a beam for their failure process. The obtained energy values are as follows.

Table - 7: Impact Strength Test Results

\begin{tabular}{|l|l|l|l|l|l|l|}
\hline $\begin{array}{l}\text { No of } \\
\text { Blows }\end{array}$ & \multicolumn{2}{|l|}{ First crack } & \multicolumn{2}{l|}{$\begin{array}{l}\text { Ultimate } \\
\text { crack }\end{array}$} & \multicolumn{2}{l|}{$\begin{array}{l}\text { Energy } \\
\text { observed by } \\
\text { beam }\end{array}$} \\
\hline & Joules & Kg-m & Joules & Kg-m & Joules & Kg-m \\
\hline 310 & 418 & 43 & 5832 & 594 & 6179 & 630 \\
\hline
\end{tabular}



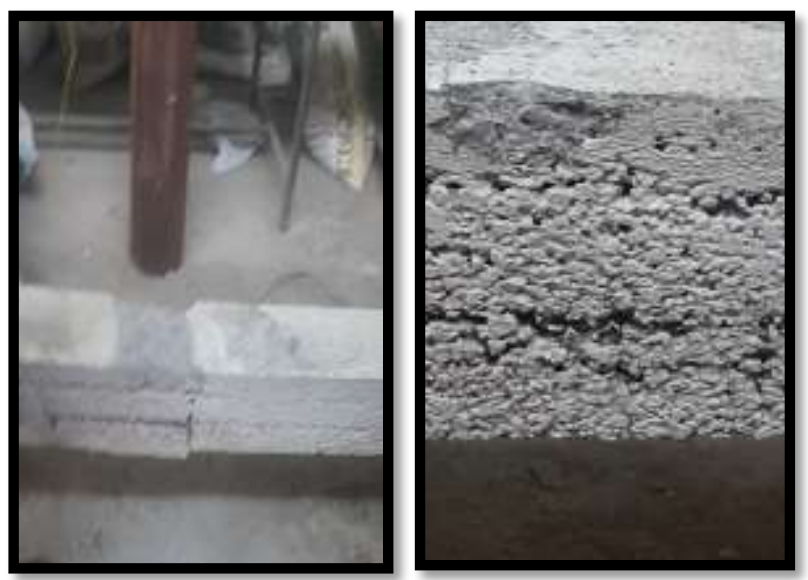

Fig -12: Impact Strength Test Cracks

From the above results it can be concluded that ferroconcrete beam has got sufficient toughness and can be comparable with Ferro cement Beam.

\section{CONCLUSION}

Based on the experimental study the following conclusion has been drawn.

- Optimum water-cement ratio to produce ferroconcrete elements is 0.45 for cement, jelly chips ratio of $1: 3$ especially for beam elements.

- Maximum compressive strength of about $16.32 \mathrm{Mpa}$ was obtained at 28days for mix proportion of $1: 3$ especially for beam elements.

- Flexural strength of beam specimens was $13.62 \mathrm{~N} / \mathrm{mm}^{2}$, which shows that it behaves like elastic material. It is not brittle material and comparable to RCC beam.

- The flexural behavior of ferroconcrete beam is almost similar to the behavior of reinforced ferro cement element. Hence jelly chips of size passing from $4.75 \mathrm{~mm}$ IS Sieve can be fully replaced with sand in the production of light weight members.

- $\quad$ The produced beam of size $150 \mathrm{X} 150 \mathrm{X} 2000 \mathrm{~mm}$ is good enough to take impact energy of 6415joules, which is comparable with RCC.

- Cost analysis of ferroconcrete and RCC beams indicate that indicate that ferroconcrete beams are economical compared to RCC for the same functional requirement.

- Jelly chips (passing from $4.75 \mathrm{~mm}$ and retained in $2.36 \mathrm{~mm}$ IS Sieve) can be used in place of sand and reinforcement bars can be replaced by GI Mesh, has these two materials to produce beam.

- Ferroconcrete building elements could be a viable area. Ferroconcrete consists of two main components the matrix and reinforcement. The matrix is cement and jelly chips as binder and the reinforcement of ferroconcrete is commonly in the form of layers of continuous mesh.

- The growing housing needs, especially in developing countries make the search for economical and adequate building units having required strength and durability.

\section{FUTURE SCOPE}

- The work can be further extended to study the permeability properties of ferroconcrete.

- Different types of meshes can be used by checking their performance also by increasing the numbers of layers of mesh in the production of ferroconcrete structural members.

- Further studies can be taken up by using pozzolonic materials such as fly ash and GGBS etc.

\section{ACKNOWLEDGEMENT}

- I would first like to thank my mom and almighty god for their blessing with which we could complete this project.

- With great pleasure I wish to express my deep sense of gratitude to my guide Mrs. Sowmyashree T, Mr. Sharath, HOD Mr. Virendra Kumara K N, and Principal Dr. S.B. Anadinni of Vijaya Vittala Institute of Technology.

- I express my sincere thanks to Mr. Satish G.A and all teaching and non teaching staff of Bangalore Institute of Technology for providing me with necessary guidance and valuable suggestions and guidance throughout the project work.

\section{REFERENCES}

[1] Shang Shouping, Zeng Linghong, Peng Hui and Fang Ping, "Flexural Behaviour of reinforced concrete beams with Ferro cement".

[2] Antoine E, Naaman and Surendra P.Shah "Tensile Tests of Ferro Cement".

[3] S.U. Khan, S.F.A. Rafeeqi and T. Ayub (2013), IJST, Transaction of Civil Engineering, Vol 37, "Strengthening of RC Beams in flexural using Ferro cement".

[4] M.S. Shetty, "Concrete Technology Theory \& Practice", published by S. Chand \& Company. 